\title{
SISTEM INFORMASI RENCANA PELAKSANAAN PEMBELAJARAN TEMATIK KELAS 1 PADA SDIT CERDAS INSANI
}

\author{
Septianingrum $^{1}$, Didik Wiguna ${ }^{2}$, Sutrisno ${ }^{3}$ \\ Program Studi Teknik Informatika, Fakultas Teknik dan Ilmu Komputer, \\ Universitas Indraprasta PGRI \\ Jalan Raya Tengah No 80, Kelurahan Gedong, Pasar Rebo, Jakarta Timur \\ ningrumsepti26@gmail.com ${ }^{1}$,didik.wiguna@gmail.com², sutrisno3831@gmail.com³
}

\begin{abstract}
Abstrak
Tujuan penelitian ini adalah untuk mengatasi masalah yang terjadi pada SDIT Cerdas Insani dalam pendataan database data RPP serta data guru, siswa dan nilai siswa agar dapat tersusun rapih, sistematis dan mudah dalam pelaporan. Pembuatan sistem ini menggunakan perangkat lunak NetBeans IDE 8.2 database MYSQL. Metodologi penelitian yang digunakan dalam sistem pengolahan data yaitu teknik pengumpulan data seperti wawancara dengan pihak terkait dan melakukan dokumentasi untuk mendapatkan informasi yang dibutuhkan. Penulis juga melakukan penelitian dengan metode kepustakaan yang relevan dengan masalah sistem pengolahan data RPP. Setelah melakukan penelitian dan analisa permasalahan serta menyelesaikan masalah yang diusulkan, maka penulis dapat menyimpulkan bahwa, sistem yang berjalan masih dilakukan dengan aplikasi sederhana menggunakan aplikasi Microsoft Office dengan dibangunnya sistem database pada SDIT Cerdas Insani bisa mempermudah bagian penginput data dalam melaksanakan tugas-tugasnya.
\end{abstract}

Kata Kunci: Rencana, Pelaksanaan, Pembelajaran, Tematik, Java

\begin{abstract}
The purpose of this research is to solve the problems that occur in SDIT Cerdas Insani in data collection of RPP data databases as well as data on teachers, students and student scores so that they can be arranged neatly, systematically and easily in reporting. Making this system using NetBeans IDE 8.2 MYSQL database software. The research methodology used in the data processing system is data collection techniques such as interviews with related parties and documentation to obtain the required information. The author also conducts research with literature methods that are relevant to the problem of RPP data processing systems. After conducting research and analyzing the problems and solving the proposed problems, the authors conclude that, the system that is still running is done with a simple application using Microsoft Office applications with the construction of a database system on SDIT Cerdas Insani can simplify the data input section in carrying out its tasks.
\end{abstract}

Keywords: Plans, Implementation, Learning, Thematic, Java

\section{PENDAHULUAN}

Mutu sistem dalam dunia pendidikan dan layanan sebuah informasi yang digunakan pada setiap sekolah juga perlu diperhatikan, sehingga dengan adanya teknologi seperti aplikasi dalam layanan informasi perencanaan pelaksanaan pembelajaran tematik kelas 1 yang dimiliki ini akan dapat memudahkan baik dari segi waktu dan tempat serta keakuratan data yang diperlukan. SDIT Cerdas Insani adalah salah satu sekolah swasta di Bekasi. Sebagai penyelenggara pendidikan yang terkelola oleh sebuah yayasan, SDIT Cerdas Insani harus berkompetisi dengan baik dalam menyelenggarakan dan memajukan generasi dunia pendidikan dalam mendidik anak bangsa.

Saat ini sistem informasi sekolah mengenai pembuatan perencanaan pelaksanaan pembelajaran yang sedang berjalan masih dilakukan secara manual di mana semua proses menginput data masih menggunakan sebuah Microsoft word secara sederhana. Tentu saja pendataan kegiatan ini kurang aman dalam penyimpanan data yang dilakukan oleh guru, serta masih sulit untuk menginput dan mencari data mengenai kegiatan perencanaan pelaksanaan pembelajaran ketika sedang dibutuhkan dan sering terjadi kehilangan data pada saat pencarian data dapat dikatakan masih kurang efektif. Oleh karena itu pendataan ini belum memiliki suatu sistem informasi yang baik dan bermutu. 
Pemakaian teknologi komputerisasi dalam dekstop dapat memberikan manfaat, baik dalam ketelitian pada saat pengolahan data maupun banyaknya pekerjaan yang ditangani. Sehingga dalam penyajian laporan dan informasi yang dibutuhkan dapat diperoleh dengan cepat, tepat dan lengkap. Menurut (Sutabri, 2012) Secara sederhana, suatu sistem dapat diartikan sebagai suatu kumpulan atau himpunan dari unsur, komponen, atau variabel yang terorganisasi, saling berinteraksi, saling tergantung satu sama lain, dan terpadu.

Menurut (Rustiadi, 2008) suatu proses menentukan apa yang ingin dicapai di masa yg akan datang serta menetapkan tahapan yang dibutuhkan untuk mencapainya.Sistem adalah suatu jaringan kerja dari prosedur yang berhubungan, terkumpul bersama-sama untuk melakukan suatu kegiatan atau tujuan tertentu. Menurut (Yakub, 2012) Sistem adalah suatu jaringan kerja dari prosedur yang berhubungan, terkumpul bersama-sama untuk melakukan suatu kegiatan atau tujuan tertentu. Menurut (Kadir, 2013) server yang berfungsi untuk menangani database. Database adalah suatu pengorganisasian data dengan tujuan memudahkan penyimpanan dan pengaksesan data. Dengan menggunakan MySQL, kita bisa menyimpan data kemudian data bisa diakses dengan cara yang mudah dan cepat.

Menurut (Shalahuddin, 2013) sistem yang terkomputerisasi yang tujuan utamanya adalah memelihara data yang sudah diolah atau informasi dan membuat informasi tersedia yang dibutuhkan. Menurut (Arifin, 2010) adalah suatu proses atau kegiatan yang sistematis yang bersifat interaktif dan komunikatif antara pendidik "guru" dengan siswa, sumber belajar, dan lingkungan untuk menciptakan suatu kondisi yang memungkinkan terjadinya tindakan belajar siswa. Menurut (Kadir, 2014) suatu pengorganisasian sekumpulan data yang saling terkait sehingga memudahkan aktivitas untuk memperoleh informasi.

Berdasarkan kebutuhan di atas, penulis menyusun sebuah skripsi untuk perancangan suatu sistem yang dapat membantu pada sekolah tersebut dalam pengelolaan data informasi yang terkomputerisasi oleh suatu program berbasis desktop yang berjudul "Sistem Informasi Rencana Pelaksanaan Pembelajaran Tematik kelas 1 pada SDIT Cerdas Insani Bekasi berbasis java”.

\section{PENELITIAN RELEVAN}

Dalam melakukan penelitian tentang Sistem informasi rencana pelaksanaan pembelajaran tematik kelas 1 Pada SDIT Cerdas Insani Bekasi berbasis Java, penulis menggunakan bahan referensi dari berbagai sumber, antara lain dari jurnal sebagai berikut :

Penelitian yang dilakukan oleh (Anshory et al., 2017), ISSN 2597 - 4122, Vol 1 No 1, yang berjudul "Pelaksanaan Pembelajaran Tematik Sesuai Kurikulum 2013 di SD Muhammadiyah 03 Wajak". Tujuan dari Penelitian untuk membuat suatu aplikasi ini adalah up-dating pengetahuan guru SD Muhammadiyah 03 Wajak tentang kurikulum 2013, Bisa mengaplikasikan pembelajaran K13 sesuai dengan kurikulum yang tidak saling berpisah satu sama lain, terutama pada mata pelajaran PJOK selalu berpisah. dengan mata pelajaran lainnya, Kembangkan sekelompok guru SD Muhammadiyah 03 Wajak, yang mandiri dalam menerapkan pelajaran tematik sesuai kurikulum tahun 2013.

Penelitian yang dilakukan oleh(Fauzi Mulyatna, Farah indrawati, 2018), ISSN 2615 - 8728, Vol 1 No 1, yang berjudul "Pelatihan Pembuatan Rencana Pelaksanaan Pembelajaran (RPP) berdasarkan Kurikulum 2013". Tujuan dari Penelitian untuk membuat suatu aplikasi memberikan penyuluhan sekaligus pelatihan perencanaan pembelajaran yang baik melalui implementasi Rencana Pelaksanaan Pembelajaran (RPP) dengan pemilihan pendekatan yang tepat berdasarkan Kurikulum 2013.

Penelitian yang dilakukan oleh (Setiadi, 2016), ISSN 2338-6061, 2338-6061, Vol 20 No 2,yang berjudul "Pelaksanaan penilaian pada Kurikulum 2013". Penelitian tentang sebuah sistem bagaimana mengimplementasi penilaian pada Kurikulum 2013 serta mengidentifikasi hambatan dan keberhasilan pelaksanaan penilaian pada Kurikulum 2013 dan memberikan rekomendasi kepada Pemerintah dalam mengambil kebijakan pelaksanaan penilaian pada Kurikulum 2013.

Dari Jurnal diatas tersebut dapat di padukan untuk menjadi sebuah sistem informasi yang lebih baik. dari segi pengolahan data serta mengatur pada kegiatan informasi data sekolah sampai efisiensi dalam 
pengerjaan kurikulum 2013 yang sering sekali menjadi kendala pada saat masih menggunakan metode tradisional.

\section{METODE PENELITIAN}

Dalam metode pada System Development Life Cycle (SPLC) berikut merupakan pendekatan pada beberapa tahap untuk menganalisa dan merancang sebuah sistem tersebut yang telah dikembangkan dengan sangat baik melalui penggunaan siklus kegiatan penganalisis dan pemakaian secara spesifik. Terdapat beberapa langka dalam pengembangan sistem dalam penulis seperti pertama Analisa Kebutuhan dalam Proses Perancangan berguna untuk mendapatkan data yang sebagai masukan suatu sistem dan memperoleh data pada proses perancangan sistem informasi rencana pelaksanaan pembelajaran tematik kelas 1 sekolah dimulai dari memahami pengguna. sebelum merancang sistem penulis harus memahami kebutuhan pengguna, apa saja yang di inginkan. Kedua Coding dan Testing berguna untuk memberikan jaminan bahwa program dapat terhindar dari kesalahan dengan melakukan pengujian dalam program. Ketiga Implementasi Program berguna untuk menguji fungsionalitas sistem informasi secara keseluruhan dan keempat Analisa Kebutuhan Setelah berguna untuk melakukan evaluasi sistem secara cepat dan efesien, serta menyempurnakan proses dalam pemeliharaan sebuah sistem dengan selalu menganilisis kebutuhan dalam informasi yang dihasilkan dan meminimalkan masalah dalam proses pemeliharaan sistem.

\section{HASIL DAN PEMBAHASAN}

\section{Analisis Permasalahan}

Berikut adalah analisis pada SDIT Cerdas Insani :

1. Pendataan data siswa dan guru serta laporan penilaian masih menggunakan media kertas (manual).

2. Pendataan data RPP masih menggunakan media sederhana seperti Ms Word

3. Penyimpanan data masih menggunakan media sederhana dan cetak (filling) sehingga sering terjadi kehilangan dan duplikat data.

4. Pencarian data RPP maupun data guru dan siwa membutuhkan waktu yang lama sehingga kurang efisien dalam waktu.

5. Pencatatan penilaian siswa secara manual memungkinkan terjadinya kesalahan pencatatan dan perhitungan nilai siswa.

6. Penyimpanan data RPP dalam bentuk cetak atau arsip rawan hilang dan sering terjadi kerusakan dokumen.

7. Pencatatan data guru, siswa dan penilaian dengan sistem manual kurang efisien, karena harus mengecek id dan mencari data satu per satu sehingga membutuhkan waktu yang lama.

\section{Alternatif Penyelesaian Masalah}

Berdasarkan analisis permasalahan yang sudah penulis uraikan diatas, alternatif pemecahan masalah yang akan penulis lakukan untuk mempermudah proses kerja pada SDIT Cerdas Insani sebagai berikut :

1. Admin langsung memasukan data guru dan siswa pada sistem dan otomatis sistem akan menentukan data sudah ada atau belum.

2. dan guru memasukan data RPP dan penilaian pada sistem dan otomatis sistem akan menentukan data sudah ada atau belum.

3. Penyimpanan media menggunakan database MySql.

4. Data siswa yang sudah ada dapat langsung menentukan penilaiannya.

5. Semua data guru, siswa, RPP dan penilaian dapat di cetak untuk kebutuhan reporting. 


\section{Use Case Diagram}

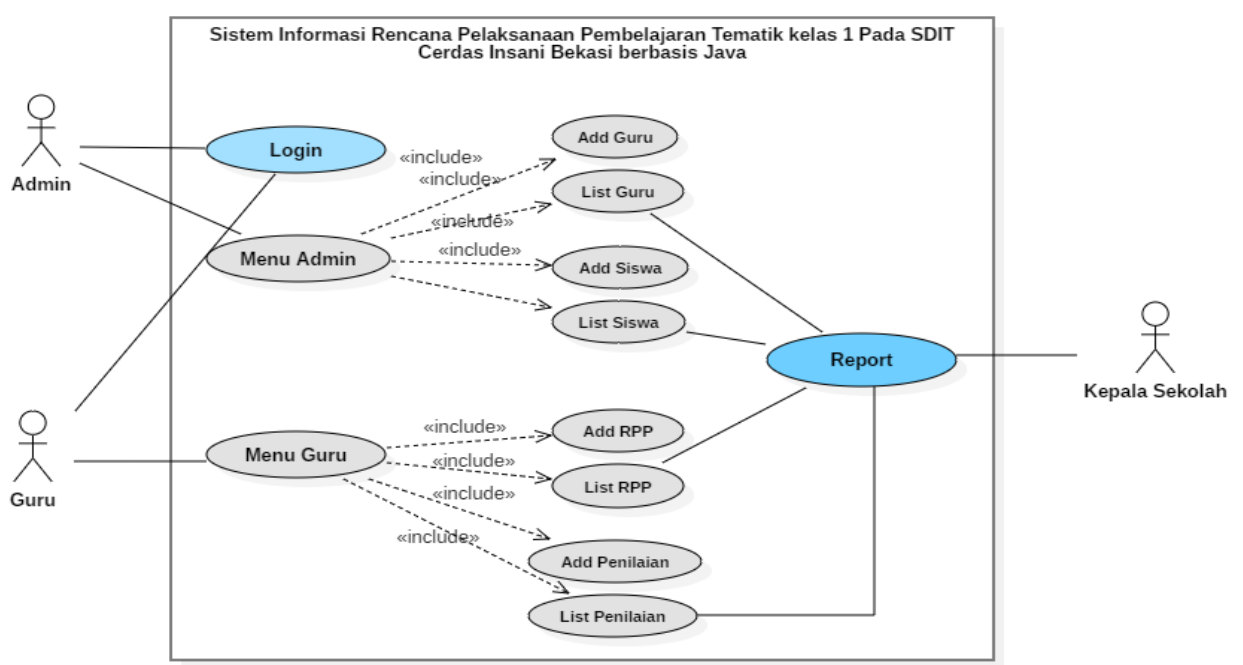

Gambar 1. Use Case Diagram

\section{Tampilan Layar Login}

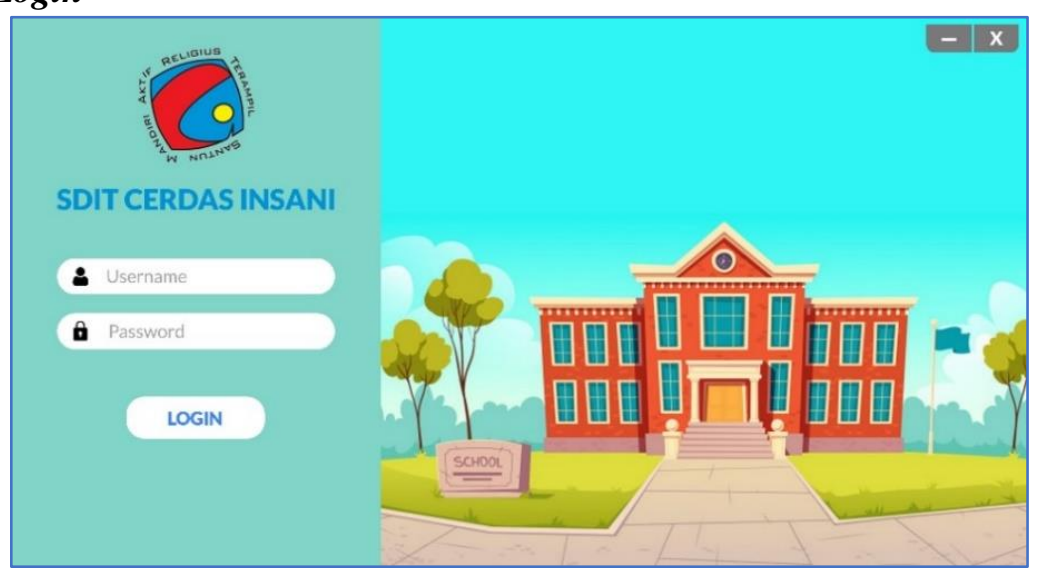

Gambar 2. Tampilan Layar Login

Halaman login ini akan tampil pada saat membuka aplikasi Sistem Informasi Administrasi Rencana Pelaksanaan Pembelajaran Tematik kelas 1 milik SDIT Cerdas Insani. Dalam menu admin ini terbagi menjadi dua level user yaitu admin dan guru. Ketika memasukan username dan password dan berhasil login maka sistem akan menentukan level dari user dan menampilkan menu yang sesuai dengan level tersebut.

\section{Tampilan Layar Menu Admin}

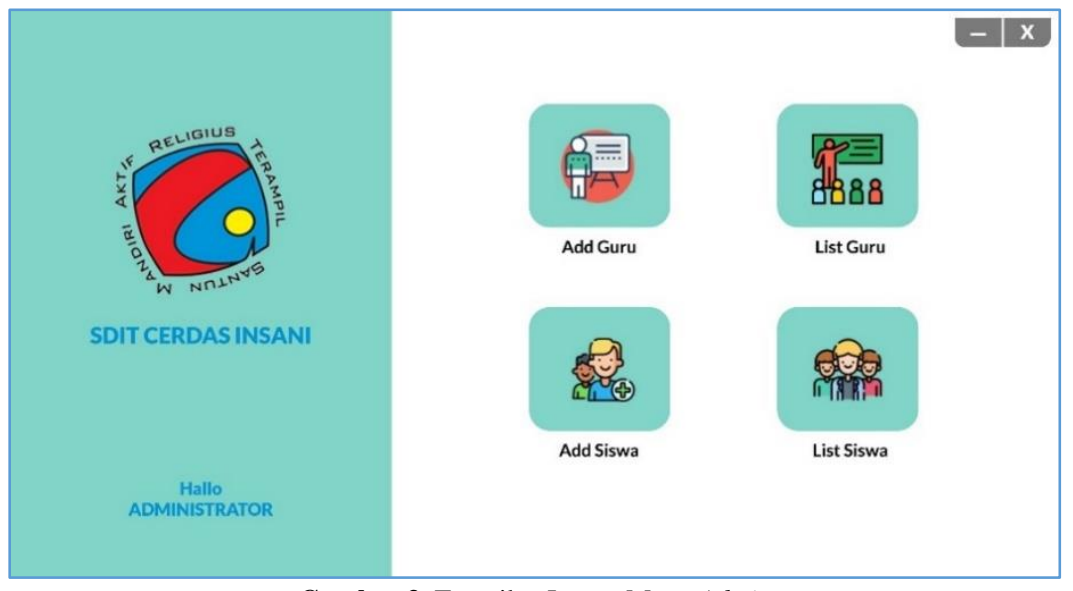

Gambar 3. Tampilan Layar Menu Admin 
Menu utama ini akan tampil ketika user yang login dengan level admin. Pada menu utama admin terdapat empat menu, yaitu menu add guru berguna untuk menambah data guru dan menu list guru untuk melihat semua data dari guru yang sudah di buat. Menu add guru dapat di gunakan untuk menambah akun guru sesuai dengan jabatan kelas masing - masing yang berada pada SDIT Cerdas Insani. Selanjutnya menu add siswa berguna untuk menambah data siswa dan menu list siswa untuk melihat semua data dari guru yang sudah di buat.

\section{Tampilan Layar Menu Guru}

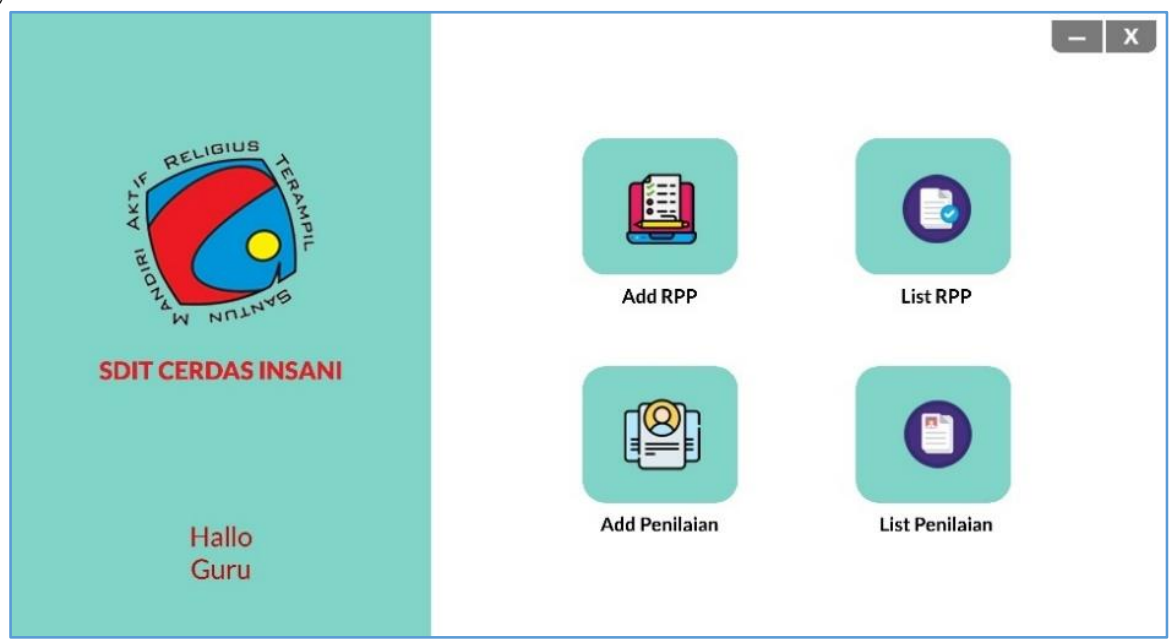

Gambar 4. Tampilan Layar Menu Guru

Menu utama ini akan tampil ketika user yang login dengan level guru. Pada menu utama guru terdapat empat menu, yaitu menu add RPP berguna untuk menambah RPP. Kemudian ada menu add penilaian berguna untuk memasukkan nilai dari data siswa yang di dapat. Lalu ada list $R P P$ yang berguna untuk menampilkan data $R P P$ yang sudah di masukkan. Dan yang terakhir terdapat menu list penilaian di mana menu tersebut bertujuan untuk menampilan data nilai setiap siswa.

\section{Tampilan Layar Print Preview Guru}

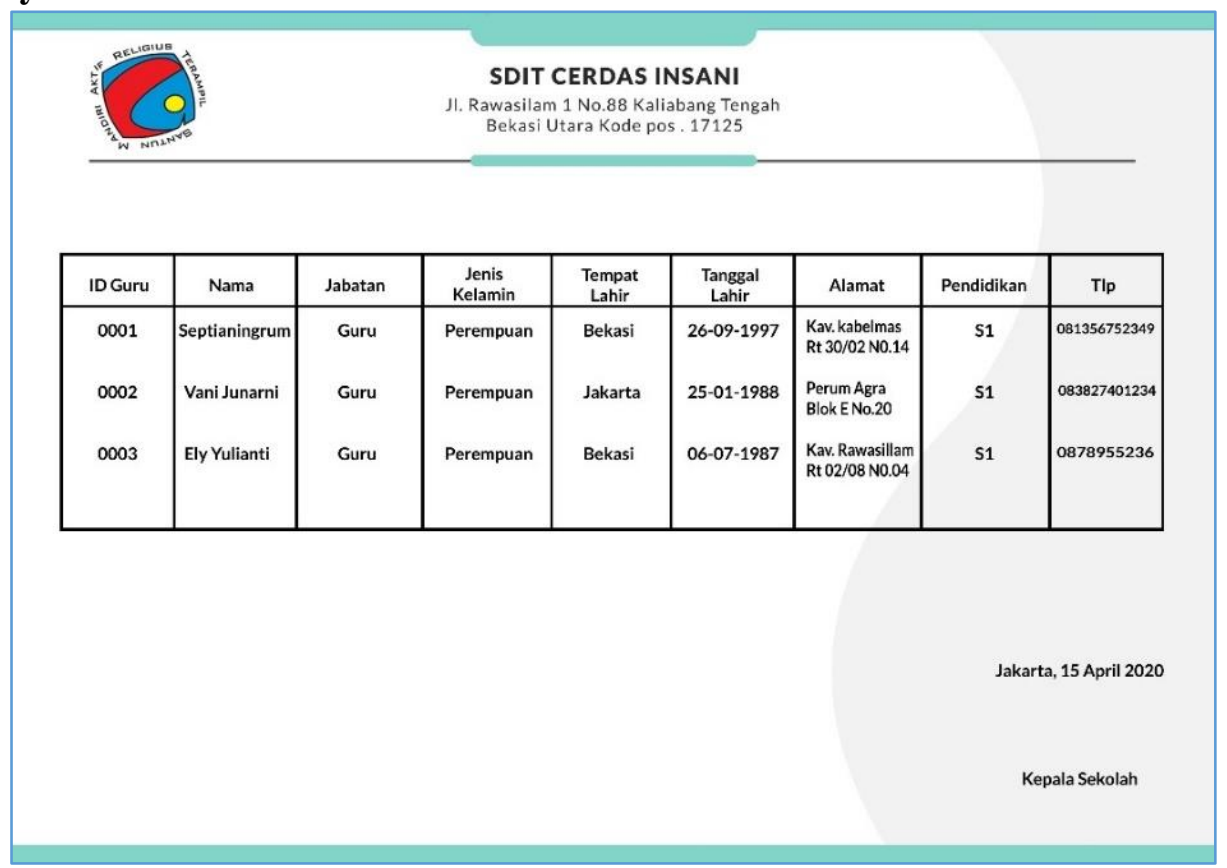

Gambar 5. Tampilan Layar Menu Guru 
Laporan data guru merupakan hasil dari cetak admin pada menu list guru. Dan akan otomatis menggunakan kopsurat dari SDIT Cerdas Insani dengan mode landscape.

\section{Tampilan Layar Print Preview Siswa}

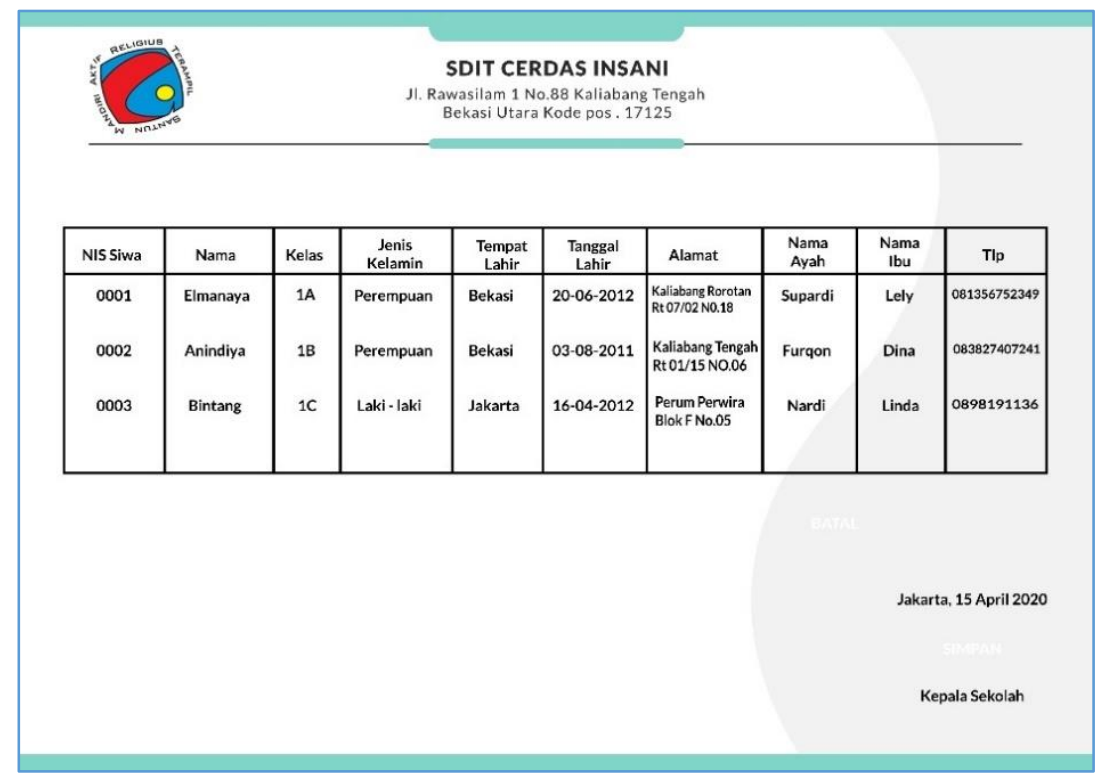

Gambar 6. Tampilan Layar Print Preview Siswa

Laporan data guru merupakan hasil dari cetak admin pada menu list guru. Dan akan otomatis menggunakan kopsurat dari SDIT Cerdas Insani dengan mode landscape.

\section{Tampilan Layar Print Preview RPP}

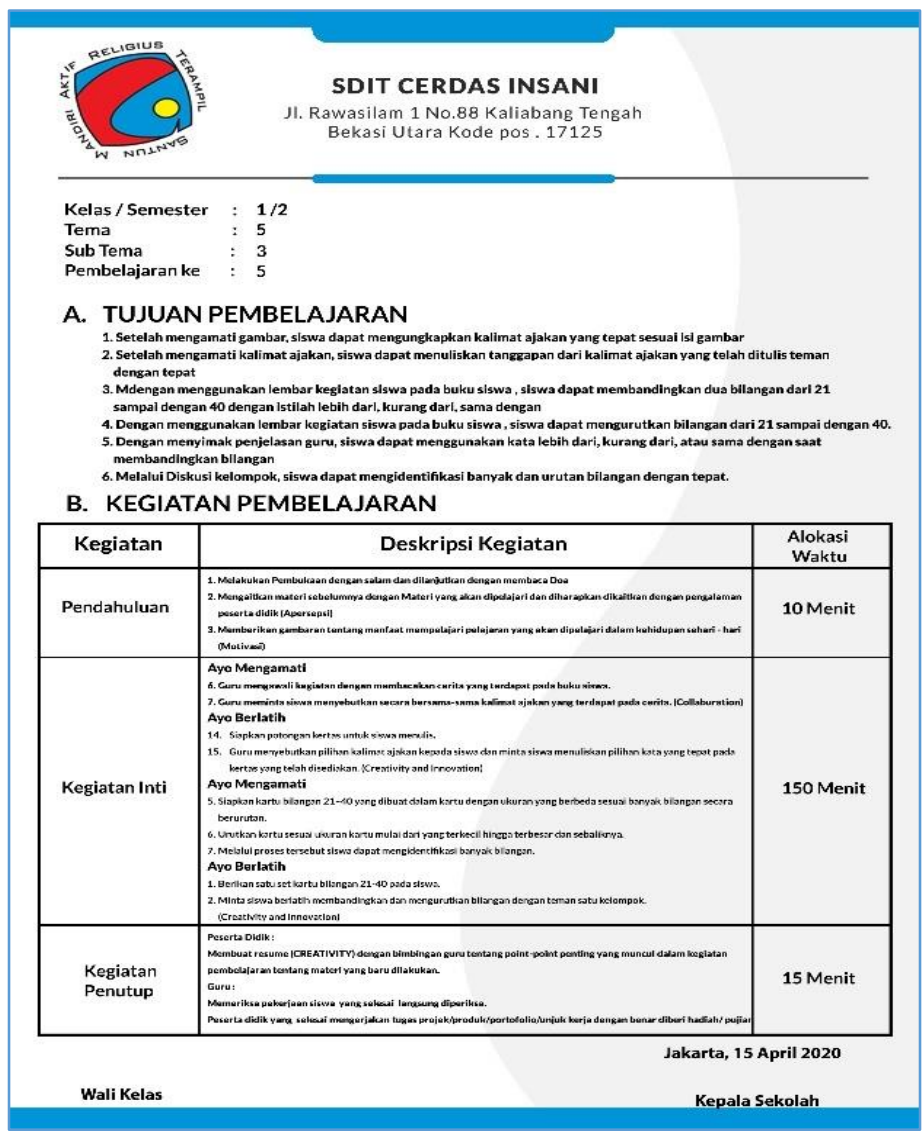

Gambar 7. Tampilan Layar Print Preview RPP 
Laporan data RPP merupakan hasil dari cetak guru pada menu list RPP. Dan akan otomatis menggunakan kopsurat dari SDIT Cerdas Insani dengan mode portrait, laporan tersebut akan diberikan kepada admin untuk filing dan bukti setelah sudah di acc dan diberi tanda tangan oleh kepala sekolah.

\section{Tampilan Layar Print Preview Penilaian}

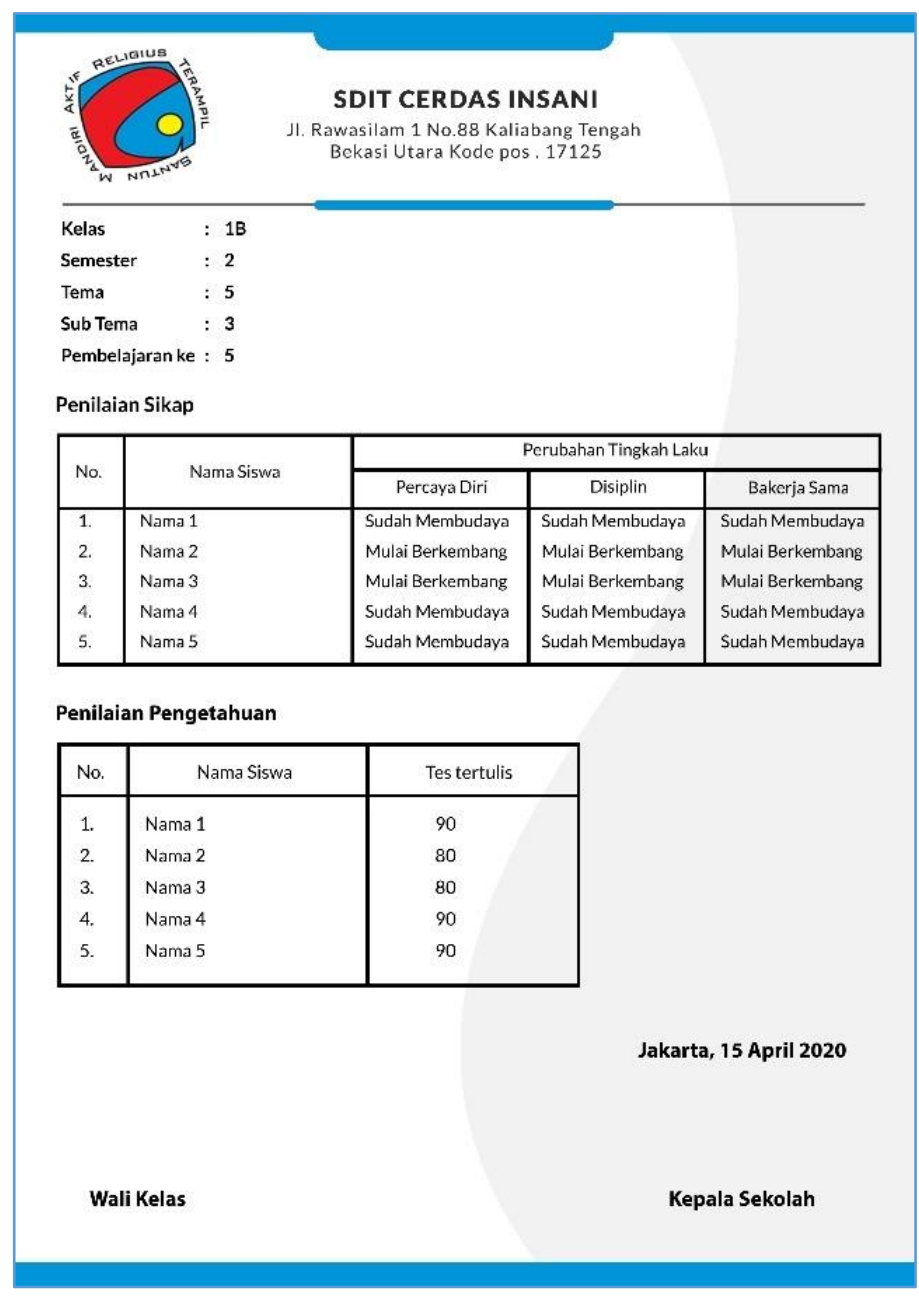

Gambar 8. Tampilan Layar Print Preview Penilaian

Laporan data penilaian merupakan hasil dari cetak guru pada menu list penilaian. Dan akan otomatis menggunakan kopsurat dari SDIT Cerdas Insani dengan mode portrait. Laporan tersebut diberikan kepada admin untuk filing dan bukti nilai saat pengambilan rapor setelah sudah di acc dan diberi tanda tangan oleh kepala sekolah.

\section{SIMPULAN}

Dengan adanya aplikasi sistem informasi rencana pelaksanaan pembelajaran tematik kelas 1 ini, segala kegiatan yang berhubungan dengan penyimpanan data, penginputan data serta laporan dilakukan tidak lagi secara manual tetapi menggunakan media berupa komputer, dengan dibuatnya sistem informasi pada SDIT Cerdas Insani ini diharapkan akan mempermudah kegiatan pengolahan data pada bagian pendataan data sekolah. Dalam penulisan ini dapat di ambil kesimpulan dengan menggunakan sistem ini berdasarkan perumusan masalah sebagai berikut:

1. Sistem informasi rencana pelaksanaan pembelajaran tematik kelas 1 ini dapat memudahkan kegiatan sekolah dalam pengolahan data serta meminimalisir risiko data rusak dan hilang.

2. Penerapan teknologi informasi dalam bentuk ini lebih menarik, lebih cepat, tidak mengenal waktu, dan dapat mempermudah kinerja guru. 
3. Mempermudah bagi kepala sekolah untuk melihat laporan data yang dibutuhkan secara efektif dan efisien

\section{DAFTAR PUSTAKA}

Anshory, I., Saputra, S. Y., \& Amelia, D. J. (2017). Pelaksanaan Pembelajaran Tematik Sesuai Kurikulum 2013 Di SD Muhammadiyah 03 Wajak, 1.

Arifin. (2010). Evaluasi pembelajaran.

Fauzi Mulyatna, Farah indrawati, L. H. (2018). Pelatihan Pembuatan Rencana Pelaksanaan Pembelajaran (RPP) Berdasarkan Kurikulum 2013, 1.

Kadir, A. (2013). Pemrograman Database MySQL untuk Pemula. Yogyakarta: Mediakom.

Kadir, A. (2014). Pengenalan Sistem Informasi Edisi Revisi. Yogyakarta: Andi.

Rustiadi. (2008). Konsep Dasar Rencana Pembelajaran Jakarta: Indeks.

Setiadi, H. (2016). Pelaksanaan penilaian pada Kurikulum 2013. Himpunan Evaluasi Pendidikan Indonesia, 20.

Shalahuddin, R. (2013). Rekayasa Perangkat Lunak Terstruktur dan Berorientasi Objek. Bandung: Informatika.

Sutabri. (2012). Konsep Dasar Informasi. Yogyakarta: Andi.

Yakub. (2012). Pengantar Sistem Informasi. Yogyakarta: Graha Ilmu. 